\title{
COMPREENDENDO A CONSTRUÇÃO DE UM ETHOS DE PODER FAMILIAR: O CASO DA OLIGARQUIA PEREIRA NO INTERIOR DE PERNAMBUCO
}

\author{
Giovanni Alves Duarte de Sá ${ }^{1}$
}

\begin{abstract}
Resumo: Nesta pesquisa investigamos mais de 200 anos de trajetória política da família Pereira, no Sertão de Pernambuco, desde o Império até a contemporaneidade. O objetivo foi compreender a construção do que chamamos de ethos de poder familiar a partir da análise de crenças e valores morais do clã, o qual vem desenvolvendo estratégias de exaltação simbólica do seu próprio sobrenome ao longo dos anos. Aliado a isto, apresentamos os resultados de um levantamento de parentelas políticas onde a família objeto deste estudo, com base na cidade de Serra Talhada, distante $417 \mathrm{~km}$ da capital Recife, conseguiu gerar uma frutífera linhagem de herdeiros que ultrapassa barreiras regionais e ocupa postos estratégicos na estrutura do Estado até os dias de hoje.
\end{abstract}

Palavras-chaves: Família. Pereiras do Pajeú. Ethos. Poder.

\section{UNDERSTANDING THE CONSTRUCTION OF ETHOS OF FAMILY POWER: THE CASE OF OLIGARQUIA PEREIRA INSIDE PERNAMBUCO}

\begin{abstract}
In this research we investigated more than 200 years of political trajectory of the Pereira family, in the Pernambuco Sertão, from the Empire until the contemporary times. The objective was to understand the construction of what we call the ethos of family power from the analysis of clan beliefs and moral values, which has been developing strategies of symbolic exaltation of its own surname over the years. Allied to this, we present the results of a survey of political relatives where the family object of this study, based in the city of Serra Talhada, $417 \mathrm{~km}$ far from Recife, was able to generate a fruitful lineage of heirs that overcomes regional barriers and occupies strategic positions in the region. state structure to this day.
\end{abstract}

Keywords: Family. Pereiras do Pajeú. Ethos. Power.

\section{Introdução}

“Tudo começa aqui. É nos municípios que se cultivam as gerações de políticos que mantêm nossas instituições presas a um passado anterior à história". Esta frase do escritor mineiro Renato Lelo de Brito (2018, p.22) nos vale de inspiração para uma análise que tem como base a cidade

\footnotetext{
${ }^{1}$ Doutorando no Programa de Pós-Graduação em Sociologia da UFPB. E-mail: giovannialvesduarte@ gmail.com O presente trabalho foi realizado com apoio da Coordenação de Aperfeiçoamento de Pessoal de Nível Superior - Brasil (CAPES).
} 
interiorana de Serra Talhada, cravada no vale do Sertão do Pajeú ${ }^{2}$ de Pernambuco, distante 417 km da capital, Recife.

É uma terra centenária, repleta de disputas de poder entre famílias de coronéis e cangaceiros, que resultaram muitas vezes em embates sangrentos pelo controle político de prefeituras, cargos na estrutura do estado em nível federal e estatual, criação de lugares de memória em favor dos ditos vencedores e, não menos, luta por prestígio em nome de grupos específicos, que perpetuam sua influência moral e institucional até hoje no lugar.

O município é berço da histórica família Pereira do Pajeú, oligarquia familiar descendente de portugueses que chegou ao Sertão pernambucano na segunda metade do século XVIII, originários, segundo as próprias construções narrativas que os Pereiras fazem de si, de uma linhagem de barões, isto é, uma família que tem laços de descendência com nobres que aportaram em Pernambuco em maior quantidade no século XVII.

Atualmente, Serra Talhada, segundo o último Censo Demográfico do IBGE, possui pouco mais de 84 mil habitantes. Devido à força comercial e a localização (fica próxima as divisas com os estados do Ceará, Paraíba e Bahia), vem atraindo um fluxo crescente de pessoas que chega a 100 mil em termos de população flutuante. O cerne da argumentação deste artigo defende que este município reúne características que sintetizam uma face nevrálgica do Nordeste e do Brasil. Por meio da trajetória de uma família pretende-se demonstrar os dramas políticos de uma região e de um país ancorado, historicamente, numa sucessão estrutural de privilégios e violências a partir da ação de grupos políticos específicos.

A família Pereira nunca deixou de lutar, por vezes de forma beligerante, pela preservação do poder, no sentido do que diria o saudoso Florestan Fernandes (2015, p.31), “do poder que se organiza para constituir a ordem e defendê-la por todos os meios".

Nosso caminho metodológico encontra na genealogia um instrumento de identificação das teias de poder e parentela dos Pereiras, identificáveis desde o Brasil Império até o contexto atual, pós Constituição de 1988. Aliado a essa ferramenta, apresentamos aos leitores valores morais contidos na construção ideológica da família. Essas crenças são compartilhadas em façanhas e agruras do grupo a partir da simbologia presente na narrativa do livro Vila Bela, os Pereiras e Outras histórias.

\footnotetext{
${ }^{2}$ O Sertão do Pajeú é uma região formada por 17 cidades, onde Serra Talhada é a maior delas, compondo um dos maiores colégios eleitorais do interior de Pernambuco, com mais de 56 mil eleitores. A história de Serra Talhada remonta à segunda metade do século XVIII, no contexto da escravidão, quando era uma fazenda localizada numa região de sesmaria concedida ao português Agostinho Nunes de Magalhães. Antes mesmo de sua emancipação, em 6 de maio de 1851, tornou-se Vila Bela, um promissor distrito da comarca de Flores. O nome da cidade faz alusão à montanha talhada pela força do tempo, cujo em seu sopé foi erguida a fazenda de Agostinho Nunes Magalhães.
} 
A obra, com 339 páginas, foi publicada por um descendente da família em 1974, o médico, pesquisador e ex-deputado estadual Luís Wilson, e relançada com atualizações numa $2^{\mathrm{a}}$ edição em 2018, financiada pelo Centro de Estudos de História Municipal (CEHM), ligado ao projeto Biblioteca Pernambucana de História Municipal, do Governo do Estado. Neste trabalho, considerado um clássico entre os Pereiras, lançam-se as bases de construção simbólica do ethos moral da família.

Em Vila Bela, os Pereiras e Outras histórias a lógica da valentia e da defesa da honra falam alto e contribuem para legitimar simbolicamente no senso comum da cidade um ethos de poder familiar ou "um modo Pereira de ser" historicamente disposto à embates, sejam armados ou por via política.

Além da análise da obra, buscamos identificar teias de poder de membros da família seguindo pistas junto à jornais de época (por meio da hemeroteca digital da Biblioteca Nacional), no site Família Pereira do Pajeú, o qual é alimentado por descendentes do grupo, em livros de genealogia escritos por membros do próprio clã, e no site Genealogia Pernambucana, que traz pistas de parentescos sobre dezenas de famílias do Sertão do estado.

Tentaremos demonstrar através destas ferramentas como este "pequeno Brasil”, oligárquico em sua gênese, fundamentou-se desde há muito tempo na coerção de classes populares e minorias étnicas, na manutenção de privilégios e na repressão violenta a grupos considerados inimigos dos interesses de famílias dominantes.

\section{Ferramentas para construção de um ethos de poder familiar}

Os Pereiras são os únicos, dentre as famílias políticas mais tradicionais de Serra Talhada ${ }^{3}$, que se mantêm empenhados na construção de um sentimento de "ser Pereira". Membros do grupo tomaram a iniciativa, nos últimos anos, de realizar o Encontro Nacional da Família Pereira do Pajeú, o qual está na sua terceira edição realizada, em 2019, no mês de novembro em um clube particular da cidade.

\footnotetext{
${ }^{3}$ Historicamente, Serra Talhada reúne cinco principais ramos familiares que exerceram influência na cultura política da cidade, sendo eles: as famílias Pereira, Inácio de Oliveira, Godoy, Carvalho e Magalhães. Em 2018, publicamos artigo que evidenciou uma trama de interpendência entre esses grupos no contexto da República Velha e mostramos como casamentos, alianças e apadrinhamentos entre eles possibilitaram a concentração de poder político na cidade até hoje. Para saber mais, ver: Honra, poder e parentela política: reflexões sociológicas a partir de um estudo de caso no sertão pernambucano (SÁ, 2018).
} 
No evento, o clã aproveita para rever novos e antigos membros afastados por força do tempo, exaltam entre si o orgulho de "ser Pereira", conversam, cantam, comem, bebem e compartilham as histórias dos antepassados, lançam livros sobre as aventuras da família e trocam informações que podem gerar a ideia de novas obras sobre eles mesmos.

Além disso, faz parte do exercício de construção simbólica do "ethos Pereira" a publicação até agora de, pelo menos, seis livros onde pesquisadores descendentes deste clã se esmeram em delinear laços de parentesco entre seus integrantes ${ }^{4}$, entoam memórias de guerras e batalhas armadas envolvendo seus heróis e destacam a linhagem política da família em diferentes contextos. Em certa medida, Serra Talhada ficou entregue historicamente à construção ideológica da cidade a partir das lentes dos escribas deste grupo.

Além de uma expertise eleitoral, fortalece os componentes simbólicos do clã um site oficial, chamado Família Pereira do Pajeú. Quem o acessa, se depara com um brasão vermelho em alusão às raízes portuguesas da família ${ }^{5}$. Na plataforma são compartilhadas informações de seus principais "guerreiros" e seus gestos de bravura e honra, quase todos coronéis de patente da extinta Guarda Nacional, prefeitos e deputados do passado que "figuraram desde o princípio da família preservando valores, lutando e deixando um valoroso clã", diz um dos textos.

Com base nas informações contidas no site, a família interpreta o sobrenome Pereira como tronco genealógico de outros clãs secundários, que são uma espécie de subgrupos direcionados a orientar-se tendo a nomenclatura Pereira como bússola social. Conforme Luís Wilson (2018, p.62), o casamento entre José Pereira da Silva e Jacinta Rodrigues, considerado o tronco genealógico da família no Sertão de Pernambuco, gerou os ramos "Pereira da Silva, Pereira Araújo, Pereira Maranhão, Pereira Aguiar, Pereira Gama, Pereira Jacobina, Pereira Nunes, Pereira Lins, Conrado de Lorena e Sá, Pereira Valões, Pereira Santos, Cassiano Pereira, Pereira França, Pereira Terto e Pereira da Luz".

Ainda, no site da família, a exaltação de uma linhagem honrada é propulsora da ideia de união entre estes sub-grupos, como justificam nestes termos: "Todos somos Pereiras. (...) A dimensão de uma família está na unificação de suas raízes culturais e da união entre os seus"; "não compartilhamos

\footnotetext{
${ }^{4}$ Os livros são: Vila Bela, os Pereiras e outras histórias (2018); Pereiras do Pajeú e Feitosas dos Inhamuns (2017); Pajeú em Chamas: o cangaço e os Pereiras (2015); A raposa do Pajeú (2018); O patriarca (2016); Serra Talhada: 250 anos de história e 150 anos de emancipação política (2019).

${ }^{5}$ Segundo Luís Wilson (2018, p.59), a família Pereira tem origem portuguesa ligada à casa de Bragança, à qual pertenceram os imperadores do Brasil. Origina-se em Pernambuco de Amadeu de Araújo Pereira, que foi capitão-mor de Ipojuca quando se deu o levante da Restauração Pernambucana, 1645. Era natural do Minho, antiga província de Portugal, limitada ao Norte pela Galiza (do qual está separada pelo rio Minho), a Oeste pelo oceano Atlântico, ao Sul pela província do Douro, e a Leste pela de Traz-os-Montes e também pela Galiza.
} 
apenas o sangue, compartilhamos os nossos sentimentos e nossas emoções"; "temos orgulho de quem somos"; "Pereira é sobrenome que não escondemos"; "família conhecida e elogiada nos anais da história nordestina". O site, no entanto, faz referência aos patriarcas, pouco destacando nominalmente lideranças femininas.

Chama atenção a recorrência de menções, nos escritos, sobre a nobreza do sobrenome, o que parece ser fonte de orgulho para as gerações atuais o fato de descenderem de uma linhagem que os liga, em especial, a Andrelino Pereira da Silva, conhecido como o Barão do Pajeú. Fazendeiro abastado, ele foi o primeiro prefeito de Serra Talhada entre 1892 a 1895.

Numa seção do site que divulga livros sobre a história do grupo, alguns de seus antepassados são lembrados como "figuras lendárias do Sertão pernambucano"; ou senhores "absolutos de famosas legendas guerreiras"; "árbitros da elegância belicosa de seu tempo"; "sertanejos mais célebres” onde "não tenha nenhuma briga em sua época que não tenham tomado parte".

\subsection{Uma ritualística de violência}

Maria Isaura de Queiroz (1976, p.45) define bem o painel social em que a família Pereira se encaixou em meados do século XVIII no sertão nordestino, durante o Brasil Imperial. Fazia parte do ideário da época a imagem do "brasileiro bom”, em que o chefe da família possuía grandes extensões de terra "mal policiada" e com poder "sobre grande quantidade de gente". Assim, "a autonomia do latifúndio, autossuficiente, juntamente com a liderança do chefe familiar, desenvolveram o espírito local; e a política municipal girava, toda ela, em torno desses interesses locais de vários municípios".

As terríveis lutas entre famílias que se desenvolveram durante a Colônia, perdurando, em certos pontos do Brasil, Império a fora até os nossos dias, onde quer que se preservasse a estrutura patriarcal da família, resultaram da colisão de interesses ou do ódio por qualquer motivo despertado entre dois desses grupos familiares. A prova de que os interesses privados estavam intimamente ligados aos interesses públicos está na forma que tomavam os conflitos: rivalidades entre duas Câmara Municipais, brigas que resultavam na fundação de novo município dentro do território do antigo; lutas pelo domínio de uma Câmara (QUEIROZ, 1976, p.46).

Em reforço a este sentido, é recorrente na narrativa construída por Luís Wilson em sua obra a percepção de que modos de interação social, diante de certos conflitos políticos da família Pereira, prescindiam de ajustes violentos, os quais - de certo modo, eram vistos como condição moral para se manter acesa a honra da família, alimentando "um sistema de vingança, de ações violentas do tipo 
self-help", como lembra Jorge Mattar Villela (2004, p.20). Afinal, "na época, para ser Pereira, não bastava ter o sangue, era preciso querer ser" (WILSON, 2018, p.328).

Essa máxima atenta para uma condição moral do ethos Pereira que dá uma forte relevância à conduta social em reforço à consanguinidade. Isto é, haveria um agir e sentir específicos a serem obedecidos para de fato alguém merecer ter Pereira no nome, mantendo uma lógica de reputações em negociação, como sugere Cláudia Marques (2002, p.182), quando nos diz que "a reputação da família, mais solidamente estabelecida - embora não excluída do palco das negociações no qual é lançada durante as interações dos grupos e dos indivíduos - se faz sentir pelos indivíduos que são seus portadores".

Nessa perspectiva, a conduta moral importa muito para o fortalecimento de laços de respeito e prestígio entre os integrantes do mesmo ciclo familiar e os de fora. Seria preciso agir como um membro do grupo, isto é, inculcar em si os atributos esperados e sustentados pela construção social que se fez do clã ao longo do tempo. Esta é uma noção que encontra ressonância na linha de pensamento que sustenta a definição de honra como interpretada por Pitt Rivers $(1965 ; 1991)^{6}$.

É possível exemplificar este sentido com base no trecho do livro de Luís Wilson, em que um dos antepassados da família, o capitão Simplício Pereira, a quem chamavam de "o demônio da selva", mata um inocente por mera trivialidade:

No mesmo almoço, um dos convivas sacudiu pela janela um osso que descarnara, atingindo o capitão. Tremeram os que assistiram à cena, prevendo o desfecho. O homem suspendeu a comida e desfez-se em desculpas. E Simplício disse-lhe o seguinte: "Coma, para morrer de barriga cheia". E, depois do almoço, matou na realidade o morador (WILSON, 2018, p.183).

Historicamente, os Pereiras tiveram a valentia como estigma por se envolverem em seguidos ritos de violência armada, seja como mantenedores da ordem social, seja como contestadores, quando não convinha com seus interesses. Tais formas de violências acabaram, entre seus membros, atreladas a valores de coragem, heroísmo e bravura dos antepassados. Muitos ocuparam posições estratégicas de comando militar e político na estrutura do Estado.

A ideia de um rito histórico de violências protagonizado pelos Pereiras desenhou-se na trajetória da família, primeiramente, quando seus antigos ícones exterminaram dezenas de indígenas

\footnotetext{
${ }^{6}$ Para Pitt-Rivers a honra tem origens centradas em duas noções principais, sendo uma delas relativa ao título de nobreza e a segunda relativa à conduta socialmente esperada por determinado indivíduo ou grupo. A honra, nesta perspectiva, teria três funções básicas sendo elas: 1) como guia de consciência, auxiliando a tomada de julgamentos e avaliações morais; 2) influenciando na maneira de cada indivíduo se conduzir perante os outros; 3) funcionando como medida de status social ao passo que ser mais honrado, reconhecido e bem visto socialmente atribui ao indivíduo grande estima e importância.
} 
à base da força do rifle para garantir a fixação da terra e a edificação de suas fazendas no Sertão pernambucano. Lilia Schwarcz (2019, p.163) lembra que essa prática "remonta ao período colonial, quando se chamou de 'descoberta' o que foi, na verdade, invasão de um território densamente povoado. (...) Não existiu, portanto, nada de idílico no (des) encontro entre indígenas e colonos".

(...) teve a família Pereira de enfrentar, vez por outra, grupos de índios armados que faziam incursões em suas propriedades, tocando fogo em tudo, valentes, defensores impiedosos da terra que ocupavam e de direito lhes pertenciam, sendo preciso era domá-los, quase que extingui-los. Era fatal o choque entre o bárbaro que julgava seu tudo o que a terra produzisse ou sobre ela vivesse, e o branco que dela queria se apossar construindo casas, abrindo roçado, povoando suas sesmarias de gado, que ele o índio, não respeitou (WILSON, 2018, p.181).

Com base na obra de Luís Wilson, foi possível mapear historicamente a trajetória de violências em que a família Pereira se envolveu por motivações políticas. Um dos primeiros eventos identificáveis ocorreu em 1831, ano de fundação da Guarda Nacional, e que marcou o início do Período Regencial no Brasil. A família sertaneja, na figura do capitão Simplício Pereira, foi convocada para fortalecer a contenção da Revolta de Pinto Madeira ${ }^{7}$, no Ceará, conhecida também como "A insurreição do Crato".

\begin{abstract}
Após a abdicação de D. Pedro I, a 7 de abril de 1831, foi convidada a família Pereira, conforme se diz, para solidificar a causa do governo da Província do Ceará. Reuniu Simplício Pereira um grupo de célebres jagunços e lutou contra o capitão de milícias Joaquim Pinto Madeira, potentado sertanejo no Cariri, que tomara parte saliente contra a Confederação do Equador (WILSON, 2018, p.183).
\end{abstract}

Os Pereiras do Pajeú também tiveram participação crucial na repressão aos fanáticos da Pedra do Reino Encantado ${ }^{8}$, no ano de 1838, em Serra Talhada, também no contexto do Brasil Imperial. Este evento ganhou força no imaginário popular nas mãos do saudoso escritor Ariano Suassuna, ao escrever o Romance da Pedra do Reino. O fenômeno do fanatismo nos sertões nordestinos, como

\footnotetext{
${ }^{7}$ Pinto Madeira, comandante das tropas das vilas do Cariri Cearense, se rebelou contra o governo Imperial quando da abdicação de D. Pedro I ao trono brasileiro. Para saber mais: https://periodicos.ufpe.br/revistas/revistaclio/article/view/24717/19992

${ }^{8}$ Hoje o território faz parte do município vizinho de São José do Belmonte. Um grupo de sertanejos, liderado por João Antônio dos Santos, fundou uma espécie de reino, com leis e costumes próprios. Seu líder era chamado de rei e usava coroa feita de cipó. Nas suas pregações, dizia que o rei Dom Sebastião, morto no período das cruzadas, lhe havia aparecido e lhe mostrara um tesouro escondido; e que o rei estaria prestes a retornar e iria transformar todos os seus seguidores em pessoas ricas, jovens, bonitas e saudáveis. O grande número de pessoas que seguiu os fanáticos preocupou o governo, os fazendeiros e a igreja. http://basilio.fundaj.gov.br/pesquisaescolar/index.php?option=com content\&view=article\&id=419\&ltemid=1
} 
destaca Rui Facó (1963; p.34), foi uma reação ao despotismo dos potentados rurais, onde pobres do campo eram vistos na condição de objetos.

$\mathrm{Na}$ análise do autor, a classe agrária dominante via no trabalhador da terra o escravo, que o era de fato e juridicamente, pois não tinham terra, nem outros bens, nem direitos. Diante da opressão do latifúndio, da concentração de privilégios em favor de algumas poucas oligarquias familiares, como a dos Pereiras, e a manutenção de desigualdades históricas surge no Nordeste:

Uma espécie de nomadismo permanente, que as secas só fazem aumentar e dá características mais trágicas. É então que se juntam ante o flagelo, reúnem nos caminhos para as longas jornadas em busca de pão e água. (...)Contra a fome e a miséria, manifestam dois tipos de reação, da parte dos pobres do campo: a formação de grupos de cangaceiros, que lutam de armas nas mãos, assaltando fazendas, saqueando comboios e armazém de víveres nas próprias cidades e vilas; e a formação de seitas de místicos, fanáticos, em torno de um beato ou conselheiro, para implorar dádivas aos céus e remir os pecados, que seriam as causas de suas desgraças.

Neste cenário de agruras, deu-se, assim, mais uma opressão violenta capitaneada pelos Pereiras, dessa vez, aos fanáticos da Pedra do Reino Encantado:

Ali, distante no máximo uma légua da Pedra do Reino Encantado, devia encontrar-se no dia 18 Simplício Pereira, como havia combinado, o comissário Manuel Pereira da Silva, para juntos marcharem sobre a Pedra Bonita, sabedores do que se passava no local. (...) Foi horrível o combate das duas forças, não podendo os homens de Manuel Pereira, utilizar ao menos as suas espingardas. A luta foi corpo a corpo com um grupo de loucos, cuja ideia era a de martírio e morte para ressureição e vida eterna, de indescritível felicidade, no Reino de São Sebastião. Depois de uma ou duas horas de combate, de fuga dos fanáticos e extermínio do Reino Encantado, em Vila Bela, restavam sobre o campo 22 cadáveres: o do Rei, com 12 de seus sectários, inclusive três mulheres (...). Depois da luta entre o pequeno grupo de Manuel Pereira e os fanáticos da Pedra do Reino, chega ao local, como havia combinado o capitão Simplício Pereira, e em outro combate com os fugitivos, perdem os adeptos do Reino Encantado mais 8 companheiros (WILSON, 2018, p.200).

Numa dimensão de como a construção de um ethos de poder familiar, gestado num passado de confrontos bélicos, pode engrandecer moralmente os membros contemporâneos, Luís Wilson (2018, p. 200) escreve que o coronel Manuel Pereira diante alguns remanescentes já rendidos após a sanguinária batalha da Pedra do Reino, agiu "elevando-se à altura de um Francisco de Assis, de um São João de Deus ou de um Mahatma Gandhi”, quando revelou-se "com uma alma imensa" ao dizer para os seus homens, ante um grupo de infelizes mulheres e crianças que lhe imploraram a vida:

Meus amigos, perdão para estes desgraçados. Para que maior desgraça que terem perdidos os seus naturais protetores e acharem-se reduzidos a este lastimável estado? Perdão para eles, para que Deus também perdoe as nossas faltas. (...) Poupemos estes infelizes que, perdidos por uma má doutrina, permitiu Deus caíssem em nossas mãos para serem salvos (WILSON, 2018, p.200). 
Anos depois, em 1848, ainda no Brasil imperial, a família Pereira do Pajeú liderou um braço armado de repressão à Revolução Praieira ${ }^{9}$, de cunho liberal e socialista, quando o movimento cresceu e saiu da capital Recife chegando no interior de Pernambuco. À época, os Pereiras faziam frente aos interesses do Partido Conservador e foram por isso agraciados com regalias administrativas, quando em 1848, “os liberais são substituídos no governo do Império pelos conservadores, fato que está relacionado com as agitações em Pernambuco" (ALENCAR, CARPI, RIBEIRO, 1996, p.155).

O comando político e militar da Comarca de Flores, a quem Serra Talhada, até então considerada Vila, era agregada antes de sua emancipação, estava nas mãos dos liberais. Justamente em retaliação ao rompante, Serra Talhada foi desmembrada tornando-se oficialmente município três anos depois, em 1851. A grosso modo, a cidade nasceu fruto de uma aspiração conservadora advinda de um projeto retrógrado de nação.

No dia 3 de novembro [de 1848], os liberais mandam uma comissão ao palácio do governo comunicar ao presidente que, agremiados e fortes como estavam em toda a província [de Pernambuco], não consentiriam que se fizessem qualquer demissão de empregados da polícia ou oficiais da Guarda Nacional. Alguns dias mais tarde foi demitido o delegado e dois subdelegados da Comarca de Flores, alegando abuso dos mesmos em suas atividades policiais. É nomeado delegado de Flores, a quem manda também o poder central que fosse entregue a Câmara e a Comarca daquela localidade, o coronel Manuel Pereira da Silva, chefe do Partido Conservador em Vila Bela. (...) O tiroteio em Flores, regurgitando de bacamartes e da fina flor do cangaceirismo do Pajeú e do Navio [região vizinha, conhecida a partir da cidade de Floresta], começou no dia 18, às 2 horas da tarde (...) Dois dias depois, quando a munição e víveres dos dois lados estavam quase esgotados, chega o capitão Simplício Pereira, à Vila Bela de Flores, com 200 homens e liquida Nogueira Paz [ex-deputado provincial de Pernambuco, líder do partido liberal na localidade e então presidente da Câmara de Vereadores de Flores], (WILSON, 2018, p.218)

Já contexto da Primeira República (1890-1930), os Pereiras entraram numa guerra sangrenta, que durou quase 20 anos, com a poderosa família Carvalho, também de Serra Talhada. No plano macro, a disputa representou, para alguns historiadores, o choque de interesses políticos das duas famílias na região pela tomada da estrutura do Estado, uma briga que teve resquícios ainda dos embates da época imperial, entre Partido Liberal, nas mãos dos Carvalhos, e o Partido Conservador, com os Pereiras (SOARES, 2015).

\footnotetext{
${ }^{9}$ A Revolta Praieira foi uma rebelião de cunho liberalista, federalista e socialista, com nítido caráter republicano e democrático, que eclodiu na província de Pernambuco entre os anos 1848 e 1850. Sendo, portanto, a última revolta liberal radical que ocorreu em Pernambuco durante o Brasil Imperial. Foram quase 30 confrontos em menos de 4 meses. Em $1^{\circ}$ de novembro de 1848 os combates chegaram ao Sertão do Pajeú (NETO, 2016).
} 
A guerra entre as famílias se estendeu no período republicano estimulada pelos ataques e revides violentos entre os dois grupos e sendo fortemente justificada por um implacável sentimento de vingança e de lavação da honra à base de sangue como destaca Luís Wilson (2018, p.231):

No princípio deste século, entre os anos de 1905 e 1922, lutam os netos e bisnetos do velho coronel José Pereira da Silva e Jacinta Rodrigues, por uma questão de vingança particular, vivendo ainda o sertão nessa época, como que o passado estágio da evolução humana, de uma sociedade de parentes em que essa forma de vingança era normal na repressão ao delito e na própria defesa da ordem social. Como que ainda na ausência de outro poder consolidado naquela região, cabia a solidariedade da família ou o clã, a prevenção e repressão dos delitos contra a vida, os interesses e a honra de seus membros.

Em outro trecho, Luís Wilson (2018, p. 243) traz o forte depoimento do coronel Antônio Pereira, que concedeu entrevista a um dos jornais da cidade, em 1917, quando estava preso na penitenciária de Fortaleza (CE), e que mostra a força moral que a questão com a família Carvalho envolveu:

Esta primeira humilhação que estou sofrendo não me enfraquece [sobre o fato de estar preso]. Não há governo que dê jeito à minha luta com os Carvalhos. É uma questão de sangue. Só Deus acabar com o último Pereira é que os Carvalhos vão deixar de ser inimigos neste mundo. O senhor quer saber de uma coisa? Lá no meu Pajeú, quando nasce um Pereira e começa a crescer, vai logo dizendo: tomara ficar homem para dar cabo de um Carvalho. A mesma coisa diz os meninos deles. É o que eu digo. É uma questão de sangue.

A luta entre Pereiras e Carvalhos cessou com a intervenção do popular líder religioso Padre Cícero, no início de 1920, que convenceu a cúpula beligerante da família Pereira a desistir de arregimentar levas de jagunços e cangaceiros na região. Estes líderes, sendo eles Sebastião Pereira (Sinhô Pereira) e Luiz Pereira da Silva (o Luiz Padre), foram aconselhados a abandonarem o sertão de Pernambuco, como assim fizeram, parando a matança.

Outro evento histórico que pudemos mapear, e que fortalece o nosso argumento de um mecanismo social de construção de um ethos de prestígio e poder familiar, foi o fato dos Pereiras terem acolhido em suas frentes de combate - ensinando, protegendo e comandando um rapaz franzino, mas já bastante valente - Virgulino Ferreira, que anos mais tarde iria tornar-se o cangaceiro Lampião.

No contexto republicano, a violência cresceu entre os Pereiras e Carvalhos a reboque da vitória política destes últimos e de seus aliados, entre 1907 e 1930, tanto em nível local como estadual. Alijados da estrutura do governo, a família Pereira deu cabo de uma série de ataques contra os Carvalhos por vingança alegando que o Estado, mediante a polícia e a Justiça, estava promovendo perseguições, prisões e humilhações em benefício de seus inimigos. 
Assim, ao longo desse tempo, os líderes bélicos da família, Sebastião Pereira (Sinhô Pereira) e Luís Padre, assumiram a marginalidade. Eles arregimentaram apoios e formaram um grande bando, tornando-se cangaceiros e, para eles, justiceiros das agruras que a família passava devido a opressão do governo, que agora pendia contra os seus. Foi quando acolheram Lampião para o seu grupo.

\begin{abstract}
No sertão da época uma coisa era certa: poder político, polícia e Justiça sempre andavam de mãos dadas, de maneira que quem detinha o poder poderia se utilizar da polícia e da Justiça em benefício próprio e com os Carvalhos não foi diferente, como tinha sido antes, com os Pereiras. As duas vezes que a vila de São Francisco foi cercada [reduto da família Pereira em Serra Talhada], agiu a polícia em conjunto com os cabras dos Carvalhos (WILSON, 2018, p.259).
\end{abstract}

Ou como exemplifica, em relato, o próprio ‘Sinhô' Pereira em entrevista concedida na década 1970, destacado por Luís Wilson (2018, p.258) em sua obra:

Os chefes políticos de nossa família solicitaram pessoalmente do governador [de Pernambuco à época] Dantas Barreto providências, que nunca chegaram. Ele reforçou os contingentes de sua polícia, em Vila Bela, que acumpliciados com os nossos inimigos, juntaram-se a grupos de civis para praticar toda sorte de hostilidades, inclusive contra esposas e filhos de nossos parentes, que não tinham, como os homens, condições para se refugiarem na caatinga.

Ao abandonarem a briga, 'Sinhô' Pereira e Luís Padre deixaram como legado à Lampião todo o seu bando e migraram para o estado de Goiás. "Homem inteligente, compreendeu Virgulino a necessidade de pertencer a um grupo mais forte. (...) Sabe-se que naquele dia, disse Sebastião Pereira a Virgulino: 'Eu vou deixar por aí algumas brasas acesas, você as apague' (WILSON, 2018, p.281).

Outro conflito armado que os herdeiros da família Pereira tomaram parte foi a Revolta de Princesa ${ }^{10}$, em 1930. Segundo Luís Wilson (2018, p.292) "um dos chefes do exército de mais de 2 mil formidáveis jagunços do Território Livre de Princesa” foi o primo de 'Sinhô' Pereira, Luís Pereira de Souza (o Luís do Triângulo) que acabou preso após aquela revolta. "Meu velho parente foi preso após a Revolução, numa pequena propriedade que possuía na Serra do Catolé [em Pernambuco] (perto da Pedra Bonita) tendo morrido há 15 ou 16 anos no Estado da Paraíba (...).

Com base nesse levantamento, é possível dizer que a construção histórica do ethos de poder familiar dos Pereiras do Pajeú esteve fortemente vinculada aos códigos de conduta dos seus antepassados. Potencializada pela ideia de honra, valentia e justiça com as próprias mãos, a violência

\footnotetext{
${ }^{10}$ A Revolta da Princesa foi um movimento rebelde liderado pelo coronel José Pereira Lima, deflagrado no município de Princesa, atual Princesa Isabel (PB), em fevereiro de 1930, em oposição ao governo estadual de João Pessoa Cavalcanti de Albuquerque. João Pessoa era também o companheiro de Getúlio Vargas na chapa da Aliança Liberal, concorrendo à vice-presidência da República nas eleições de $1^{\circ}$ de março daquele ano. Para saber mais: https://cpdoc.fgv.br/sites/default/files/verbetes/primeira-republica/PRINCESA,\%20Revolta\%20de.pdf
} 
- esta que nunca foi insólita na trajetória da família - ajudou a forjar no imaginário popular de Serra Talhada um estigma social sobre os Pereiras. O que reflete, em certa medida, uma condição que serve de guia moral e motivo de orgulho para alguns de seus membros na atualidade.

Vê-se aqui um trabalho de construção de naturalização do ethos de poder familiar, reproduzido também no engajamento político. Participar do poder foi uma constante da família Pereira não só em Serra Talhada, mas em outras cidades do Sertão pernambucano e, ainda, em outros estados, como iremos constatar. Aliada a outros componentes práticos, a ideia de um capital moral-familiar herdado desde muito com base na conduta social de seus antigos membros -, se apresenta como um forte elemento de distinção para a política e mesmo de diferenciação social.

\subsection{Uma oligarquia que se renova ${ }^{11}$}

Como sugere Lewin (1993, p.14-15), a oligarquia brota já no Brasil imperial, apesar de associada comumente à República Velha, e resultou do casamento de um sistema eleitoral nacional com os interesses de clãs parentais (clã familiares extensos), os quais, por volta do período colonial, expandiram-se energicamente "absorvendo as grandes propriedades fundiárias da sociedade rural e as populações delas dependentes". Assim, “o surgimento dos partidos políticos, na década de 1840, impeliu para a esfera pública do município as famílias extensas poderosas, transformando clãs parentais em clãs eleitorais".

Nessa época, se projetaram vários chefes políticos da família Pereira do Pajeú, a partir de um único tronco genealógico, o do capitão José Pereira da Silva ${ }^{12}$, “considerado o patriarca da família Pereira do Pajeú e o maior detentor de escravos dentre os seus contemporâneos locais" (NEVES, 2017, p.25). José Pereira da Silva, na segunda metade do século XVIII, recebeu como dote do sogro

\footnotetext{
${ }^{11}$ Concordamos com Maria Isaura Pereira de Queiroz (1975) quando reflete sobre oligarquias como grupos que controlam determinados setores da economia e exercem o comando da política local, ou representam grupos de parentes consanguíneos ou unidos por laços de compadrio ou matrimônio, ou, ainda, por identidade de interesses econômicos e políticos.

${ }^{12}$ Nos últimos 15 ou 20 anos do século XVIII chegou um dia à Fazenda Inveja, próxima a Serra Talhada, um rapaz cujo nome era José Pereira da Silva, egresso das sesmarias do Alto Jaguaribe (nos Inhamuns) no Ceará, dependente até o ano de 1799 da Capitania de Pernambuco. Na época em que José Pereira da Silva chegou ao Sertão do Estado, a Fazenda Inveja era arrendada ou já propriedade da família Carvalho, da qual mais tarde os Pereiras seriam inimigos. Vaqueiro, à princípio daquela fazenda, José Pereira da Silva casou tempos depois com Jacinta Rodrigues (ou Jacinta Océlia de Santo Antônio), filha do abastado fazendeiro José Carlos Rodrigues, remanescente dos fundadores da Casa da Torre (WILSON, 2018).
} 
- o abastado capitão Carlos José Rodrigues - a chamada fazenda Carnaúba, ao casar-se com sua filha, Jacinta Rodrigues.

No ato de entrega, a fazenda já possuía, além de uma leva de escravos:

Um bom número de bois, vacas, animais para o labor do campo, terrenos próprios para roçado, capoeiras e mangas para o sustento de animais de carga, que tudo isso fez entrega José Carlos Rodrigues a José Pereira, já agora membro de sua família de modo que este se integralizou de maneira completa na posse e domínio de seu novo lar e haveres. (...) Há quem diga que José Pereira da Silva, do mesmo modo que José Carlos Rodrigues (seu sogro) era um remanescente da Casa da Torre, na Bahia, da qual o fundador foi o fidalgo Garcia D’ávila, que chegou no dia 29 de março de 1549, com a comitiva do primeiro Governador Geral do Brasil, Thomé de Souza, obtendo logo as primeiras concessões de terra, transformando-se mais tarde no maior latifundiário do país (WILSON, 2018, p.63-64)

José Pereira da Silva faleceu em 1836 em Serra Talhada. Da sua linhagem com Jacinta Rodrigues, identificamos uma herança de poder transmitida para quatro gerações de filhos, netos, bisnetos e tetranetos que assumiram prefeituras, Câmaras, Assembleias Legislativas, Congresso Nacional, patentes de coronel, cargos de delegado, juiz, promotor e secretários de governo em diferentes momentos no sertão de Pernambuco e em outros estados ${ }^{13}$. A relação estreita entre Pereiras e o poder ocorreu ao longo do Segundo Império, remodelando-se na República Velha, após a Revolução de 1930, Ditadura Militar (1964-1985), sendo reatualizada no contexto democrático pós 1988, como veremos.

José Pereira da Silva teve 13 filhos com Jacinta Rodrigues. Apesar de todos praticamente terem ocupado posições relevantes como prósperos fazendeiros e, ao mesmo tempo, ativos oficiais da Guarda Nacional, daremos atenção àqueles com descendentes que usufruíram de um capital político familiar (MONTEIRO, 2016) numa perspectiva geracional de maior relevância.

\subsubsection{Herança de poder}

\footnotetext{
13 Até o momento descobrimos parentelas políticas dos Pereiras em Pernambuco, Alagoas e Tocantins. Estamos investigando indícios da herança política da família nos estados do Ceará e Paraíba. É possível, mas não se sabe ao certo, que o famoso coronel José Pereira Lima, de Princesa Isabel, na Paraíba, faça parte dessa linhagem. Tem-se a certeza, contudo, que este coronel, filho de Marcolino Pereira Lima e Aguida Andrade Lima, mantinha uma estreita relação com Serra Talhada, especialmente, com o ramo dos Pereira Gavião, que mantinham um reduto ao norte do distrito rural de Água Branca, em Serra Talhada, já na divisa entre Pernambuco e Paraíba. Após a vitória da Revolução de 1930, que depôs o governo de Washington Luís e colocou Getúlio Vargas na chefia do governo provisório, José Pereira, temendo a prisão, permaneceu foragido por quatro anos. Beneficiado pela anistia em 1934, deixou a clandestinidade e instalou-se em Serra Talhada, indo morar na fazenda Abóboras, que era do cunhado dele, o coronel Marçal Diniz. Informação obtida por meio de entrevista com o pesquisador e historiador local Luiz Ferraz Filho.
} 
Da linhagem de José Pereira da Silva e Jacinta Rodrigues comecemos falando do filho do casal, o coronel Manuel Pereira da Silva (1797-1862), considerado "um dos mais importantes membros da família Pereira do Pajeú" (NEVES, p.2017). No contexto imperial, após a morte dos pais tornou-se o chefe político do clã, assumindo terras, escravos e liderando o Partido Conservador na região.

Teve seis filhos. Um deles (neto de José Pereira e Jacinta Rodrigues), o coronel da Guarda Nacional Andrelino Pereira da Silva, foi Intendente do Município e condecorado com o título de Barão do Pajeú em dezembro de 1888 (hoje é o nome da principal praça de Serra Talhada). Já no contexto republicano, de 1892 a 1895 foi o primeiro prefeito da cidade.

Outro neto de José Pereira da Silva e Jacinta Rodrigues foi Manuel Pereira da Silva Jacobina, eleito segundo prefeito de Serra Talhada de 1895 a 1898. Morreu assassinado em 20 de outubro de 1907, fruto da guerra com a família Carvalho. Era pai de Luiz Pereira da Silva (o Luís Padre), um dos chefes bélicos da família no início século XX. O filho de Andrelino Pereira da Silva, o Barão do Pajeú, (e já bisneto de José Pereira e Jacinta Rodrigues), Antônio Andrelino Pereira da Silva, foi o terceiro prefeito da cidade de 1898 a 1901.

Mais um neto do tronco genealógico entre José Pereira da Silva e Jacinta Rodrigues foi Manoel Pereira Lins (o Né da Carnaúba). Este tornou-se prefeito da cidade vizinha a Serra Talhada, São José do Belmonte (no Sertão Central de Pernambuco), entre 1902 e 1904. Também assumiu o cargo de vereador em Serra Talhada por três legislaturas (de 1922 a 1928).

O seu filho, Argemiro Pereira de Menezes (bisneto do tronco Jacinta e José Pereira) foi deputado estadual por Pernambuco sendo eleito por oito mandatos para a Assembleia Legislativa, sendo o parlamentar mais longevo da história da cidade (de 1958 a 1990). Foi eleito também vereador em Serra Talhada por três mandatos (de 1947 a 1958), passando pelos partidos UDN, Arena, PDS, PFL, PRN e PDT.

Argemiro Pereira faleceu em fevereiro de 2011, aos 96 anos, deixando três filhos para a política (e, assim, tataranetos do tronco Jacinta e José Pereira) sendo eles: Hildo Pereira de Menezes, prefeito de Serra Talhada de 1964 a 1969, e de 1977 a 1983; Nildo Pereira de Menezes, que assumiu o comando do município entre 1969 e 1973; e Gildo Pereira de Menezes, vereador por Serra Talhada na década de 1990 por várias legislaturas.

O quarto filho, Argemiro Pereira de Menezes Filho, não entrou para a política, mas tomou conta, até falecer em agosto de 2019, da concessão pública de uma rádio da família (Rádio Cultura FM). A emissora, de grande audiência da cidade, continua em posse dos Pereiras. 
Em outra frente familiar, surge Carlos Evandro Pereira de Menezes, primo de Argemiro, mais um da quarta geração da linhagem de José Pereira da Silva e Jacinta Rodrigues. Este por sua vez, agora no contexto pós 1988, foi vice-prefeito de Serra Talhada (1993-1997) e, anos mais tarde, tornou-se prefeito da cidade por dois mandatos consecutivos, de 2005-2012, elegendo o seu sucessor. Nas eleições municipais de 2000, perdeu o embate rumo ao cargo de prefeito para o primo, Genivaldo Pereira (o Geni Pereira). Atualmente, Carlos Evandro vem sendo cotado como nome da oposição para voltar à prefeitura em 2021.

Cogita-se para esta disputa eleitoral, até o momento, lançar como nome do governo a sua prima, Márcia Conrado de Lorena e Sá, que é atual secretária de Saúde de Serra Talhada. Teríamos, portanto, o clã Pereira rivalizando o poder entre si em pleno século XXI. A linhagem de Márcia Conrado descende também do tronco, forjado no Brasil Império, de José Pereira Lima e Jacinta Rodrigues.

O pai dela, Isivaldo Conrado de Lorena e Sá, foi eleito vereador em Serra Talhada por três mandatos (1997 a 2001; 2001 a 2005; 2005 a 2009). Sua mãe, Alice Conrado, foi a vereadora mais votada da cidade nas eleições de 2016. O principal representante da linhagem Conrado de Lorena e Sá, no contexto pós 1930 em Serra Talhada, foi Luiz Conrado de Lorena e Sá.

Já falecido, este foi um chefe político temido, prefeito em Serra Talhada aos 17 anos entre 1945 e 1946; depois reassumindo de 1955 a 1958; e posteriormente voltando ao poder de 1964 a 1969. Ao longo das décadas de 1950 e 1970, Luiz Lorena revezou o poder com os parentes já citados anteriormente, Nildo e Hildo.

Um outro relevante braço político da família Pereira descende de Antônio Pereira da Silva, um dos 13 filhos do tronco genealógico José Pereira da Silva e Jacinta Rodrigues. Antônio deixou como descendente Antônia Pereira de Souza (conhecida por Sinharinha). ${ }^{14}$ No início do século passado, ela casou-se com o major da Guarda Nacional e dono de várias fazendas na região Sebastião Inácio de Oliveira (o Baião Inácio), inaugurando uma frutífera parentela política.

Dessa linhagem entre as famílias Pereira e Inácio Oliveira, descendem o ex-deputado estadual Sebastião Inácio de Oliveira Neto, eleito pela primeira vez para Assembleia de 1963 a 1966. No ano seguinte, renovou o mandato (1967/1968) e foi nomeado conselheiro do Tribunal de Contas de Pernambuco (TCE), onde tornou-se presidente do Tribunal de Contas entre 1976 e 1977; e de 1987 a 1988.

\footnotetext{
${ }^{14}$ Por receio, na época da sangrenta rivalidade com a família Carvalho, "Sinharinha" trocou o sobrenome Pereira para Nunes de Souza.
} 
Um de seus filhos, com Célia Maria de Andrada Oliveira, chama-se Sebastião Inácio de Oliveira Júnior que, por sua vez, foi deputado estadual em Pernambuco por dois mandatos (20062011 e 2012-2016), pelo antigo PFL. Atualmente, está no seu segundo mandato para deputado federal pelo PR (atualmente PL, de 2014-2018 e de 2019-2023). Foi Secretário de Transportes de Pernambuco nas gestões dos governadores Eduardo Campos e Paulo Câmara. Hoje o irmão de Sebastião Oliveira Junior, Waldemar Oliveira, é suplente de Humberto Costa (PT) no Senado Federal e presidente estadual do Avante.

Dessa mesma linhagem familiar surge Inocêncio Oliveira, que é primo e fiador político de Sebastião Oliveira Júnior, o qual absorveu o seu espólio eleitoral após sua aposentadoria em 2011. Inocêncio foi deputado federal por 10 mandatos, assumindo pela primeira vez o cargo em 1975. Ao longo desse período, patrocinou o apoio a parentes e aliados para o comando da Prefeitura de Serra Talhada. O seu neto, Victor Oliveira, concorreu às eleições municipais para prefeito em 2016, perdendo o pleito. Inocêncio chegou a assumir a presidência da Câmara dos Deputados e passou pelos partidos ARENA, PDS, PFL e PR.

Seu irmão, Sebastião Andrada de Oliveira (o Tião Oliveira), foi responsável por colocá-lo na política. O ‘Tião’ foi vereador de 1963 a 1969, logo depois passou a vice-prefeito em 1969/1973, e posteriormente elegeu-se prefeito de Serra Talhada pela primeira vez de 1973 a 1977. Em 1990 candidatou-se a deputado estadual, vencendo o pleito. Saindo da Assembleia Legislativa, voltou a candidatar-se a prefeito, vencendo a disputa em Serra Talhada para o exercício 1996/2000. Anos mais tarde, após sua morte, sua filha iria se eleger vereadora por um mandato.

Como a linhagem dos Pereiras, o clã de sua parentela por meio de Inocêncio Oliveira - mantém hoje em Serra Talhada a propriedade de uma emissora de rádio (a Líder do Vale FM), e de uma concessão de televisão em Caruaru (PE) - TV Asa Branca, retransmissora da programação da Rede Globo. ${ }^{15}$

Tivemos a preocupação de seguir pistas de parentelas políticas dos Pereiras do Pajeú para além do Sertão de Pernambuco. Logo nas primeiras buscas, nos deparamos com Hagahús Araújo, deputado federal pelo Tocantins de 1991 a 1995. Hagahús é filho do já mencionado Luiz Pereira da Silva (o Luiz Padre - neto do Barão do Pajeú), um dos líderes da luta armada contra a família Carvalho no início do século XX em Serra Talhada.

15 Para mais detalhes acessar: http://www.fgv.br/cpdoc/acervo/dicionarios/verbete-biografico/inocencio-gomes-deoliveira 
Após abandonar a matança no Sertão e viajando ao lado do primo Sebastião Pereira (o Sinhô Pereira), Luiz Padre - agora usando um outro nome para evitar que a vingança não lhe perseguisse chega ao interior de Goiás em 1919, cidade hoje chamada Dianópolis. Lá, se casa com Amélia Póvoa Araújo, integrante de uma família tradicional e abastada da região. Assim, pela ala paterna, nasce Hagahús Araújo ligado ao tronco genealógico da família Pereira do Pajeú, fazendo parte da quarta geração de figuras políticas do clã sertanejo.

Não muito diferente dos parentes pernambucanos, Hagahús, nascido em 1928, tornou-se prefeito de Dianópolis em 1964, cidade hoje agregada ao estado do Tocantins. Assumiu ainda a Secretaria de Desenvolvimento do Estado de Goiás (1983-1985), foi deputado estadual em 1982, e reeleito para a Assembleia em 1986 até chegar à Câmara Federal na década seguinte, pelo Tocantins.

Também encontramos a parentela política dos Pereira do Pajeú em Arapiraca, cidade de mais de 200 mil habitantes no Agreste de Alagoas. O ex-prefeito do município, Luiz Pereira Lima, que migrou de Serra Talhada para aquela região por volta de 1928, é bisneto do tronco genealógico José Pereira da Silva e Jacinta Rodrigues. Foi eleito prefeito de Arapiraca de 1948 a 1951. Durante muitos anos comandou a ala política conhecida como "os caras-pretas" na cidade.

Elegeu dois de seus filhos para a Assembleia Legislativa de Alagoas, Claudenor de Albuquerque Lima por quatro mandatos (1951/1954, 1955/1958, 1959/1962 e 1963/1966) e Cláudio de Albuquerque Lima (por um mandato). Luiz Pereira Lima também elegeu o genro prefeito de Arapiraca, o juiz Coaracy da Mata Fonseca. O primo de Luiz Pereira Lima, Francisco Pereira Lima, outro natural de Serra Talhada que se deslocou até aquela região, também acabou prefeito de Arapiraca

Concluímos esta investigação identificando não menos outra importante parentela política que fortalece a tese de retorno ao poder dos Pereiras a partir de 1930 no Sertão de Pernambuco. Fala-se do parentesco entre os Pereiras do Pajeú e o serra-talhadense Agamenon Sérgio de Godoy Magalhães, um velho conhecido dos anais da história política do país.

Agamenon foi ex-deputado estadual (1919 a 1924), eleito pela primeira vez com o apoio eleitoral da família Pereira em Serra Talhada. ${ }^{16}$ Também foi ex-deputado federal (1924 a 1929), Ministro do Trabalho (1934), interventor federal em Pernambuco (1937 a 1945), ministro da Justiça do governo Getúlio Vargas (1945) e governador eleito por Pernambuco de 1951 a 1952.

\footnotetext{
${ }^{16}$ Em 1919, Agamenon foi eleito deputado estadual com o apoio da família Pereira, que na época estava alijada do poder. No polo rival, a família Carvalho elegeu Solidônio Leite. Informação obtida por meio de entrevista com o historiador e pesquisador local Luiz Ferraz Filho.
} 
Sebastião Pereira (o Sinhô Pereira) em entrevista ao Jornal do Brasil, em 1969, revelou a forte ligação que o clã Pereira mantinha com Agamenon.

\begin{abstract}
Quando eu vim do Norte [em 1922], nossos inimigos é que estavam no governo em Serra Talhada [os Carvalhos e seus aliados]. Quando minha família passou a mandar a partir de 1935, no governo Agamenon Magalhães, eles mandaram me chamar [para voltar a Pernambuco]. O pai dele Sérgio Magalhães, era primo legítimo de minha mãe. As mães eram irmãs. E eu não quis ir. Nessa terra eu encontrei paz.
\end{abstract}

A partir deste levantamento é possível afirmar que a oligarquia Pereira, no Sertão de Pernambuco, se renovou através de seus herdeiros se afastando de "velhas práticas", principalmente no tocante à violência institucionalizada, mas mantiveram-se vinculados a valores que legitimaram uma espécie de "missão política". O que contribuiria para fortalecer o ethos de distinção dos Pereiras no contexto da redemocratização forjando sobre a família a crença de uma relação natural com cargos ou postos de autoridade.

\title{
Considerações finais
}

Concordando com Ricardo Costa de Oliveira (2018, p.31), de que só é possível entender a "estrutura social brasileira se compreendermos como uma estrutura genealógica", avaliamos a trajetória dos Pereiras do Pajeú como uma herança ininterrupta de poder gestado há mais de 200 anos, desde que os primeiros antepassados da família se estabeleceram no Sertão do Pajeú abrindo fazendas, acumulando escravos e dizimando indígenas a partir dos "últimos 15 ou 20 anos do século XVIII" (WILSON, p. 2018, p.59).

Nessa época, "escravidão e grande propriedade não constituíam ambiente favorável à formação de futuros cidadãos" (CARVALHO, 2017, p.27), mas esse sistema não continua reproduzindo seus valores, com avanços e retrocessos, na atualidade? O familismo político é um de seus reflexos. O que significa dizer que as lutas por cidadania no Nordeste e no país enfrentam ainda o peso de um passado de privilégios, segregação, violência institucionalizada e autoritarismo, como tentamos demonstrar.

Este contexto de desigualdades estruturais reflete, nada menos, que uma condição histórica reproduzida em inúmeras cidades brasileiras. Em outras palavras, haveria uma lógica de poder, gestado no mandonismo do Brasil colônia, que de tão presente e naturalizada foi transplantada para as regiões menores (SCHWARCZ, 2019). 
Os Pereiras já tinham o comando político de Serra Talhada muito antes da emancipação do município em 1851. No cenário republicano assumiram a prefeitura de 1890 a 1907; de 1958 a 1982; de 1982 a 1992 (apoiando a parentela Inácio Oliveira); de 1992 a 1996 (a família Carvalho com os Pereiras na vice); de 1996 a 2000 (dando apoio novamente à família Inácio) e de 2000 a 2012.

Nas eleições municipais de 2020, os subgrupos Pereira de Menezes e Conrado de Lorena e Sá deverão concorrer como oposição e vice. Atualmente, o tronco Pereira mantém cinco membros na Câmara Municipal (de um total de 17 vereadores), respeitando uma longa tradição de eleições legislativas. Portanto, as parentelas identificadas nesta pesquisa reforçaram ao longo de muitas décadas uma "rede política entrelaçada que assegura os interesses e garante a sustentação da oligarquia" (LEWIN, 1993, p. 10).

Este é o cenário de um município conservador em sua gênese histórica, mas que aponta para a discussão em que a esfera local reflete um espectro nacional. A trajetória dos Pereiras do Pajeú encontra ressonâncias não somente numa herança escravista e de reforço econômico e político a desigualdades. Mas também numa questão moral fundante de um pensamento anti-democrático. Isto é, a partir de valores de combate a movimentos e grupos que ousaram reivindicar, ao longo dos séculos, direitos coletivos universais.

\section{Referências}

ALENCAR, Chico. CARPI, Lucia. RIBEIRO, Marcus. História da Sociedade Brasileira. Rio de Janeiro: Editora ao Livro Técnico, 1996.

BRITO, Renato Lelo. Uma cidade exemplar. In: SALLES, João Moreira. Anais da Democracia Brasileira. Revista Piauí. Outubro, 2018.

CARVALHO, José Murilo. Cidadania no Brasil. O longo caminho. Rio de Janeiro: Civilização Brasileira, 2017.

FACÓ, Rui. Cangaceiros e fanáticos. Rio de Janeiro: Civilização Brasileira, 1980.

FERNANDES, Florestan. Poder e contrapoder na América Latina. $2^{\mathrm{a}}$ ed. São Paulo: Expressão Popular, 2015.

LEWIN, Linda. Política e Parentela na Paraíba: Um estudo de caso da oligarquia de base familiar. Rio de Janeiro: Record, 1993.

MARQUES, Ana Cláudia. Intrigas e Questões: vingança de família e tramas sociais no Sertão de Pernambuco. Rio de Janeiro: Relume Dumará, 2002. 
MONTEIRO, José Marciano. A política como negócio de família: para uma sociologia política das elites e do poder político familiar. São Paulo: LiberArs, 2016.

NETO, Antônio. Breve histórico de revoltas e revoluções em Pernambuco. Recife: Novo Estilo Edição do Autor, 2016

NEVES, Venício Feitosa. Pereiras do Pajeú e Feitosas dos Inhamuns. História e Genealogia. Cajazeiras (PB): Editora Real, 2017.

OLIVEIRA, Ricardo Costa. Como definir família? In: OLIVEIRA, Ricardo Costa (org.). Família importa e explica: instituições políticas e parentesco no Brasil. São Paulo: LiberArs, 2018.

PITT-RIVERS, J. Honra e posição social. In: PERISTIANY, J. G. (org.). Honra e vergonha. Lisboa: Fundação Calouste Gulbenkian. 1965.

. A doença da honra. In: GAUTHERON, M. A honra: dom de si ou ideal equívoco.

Porto Alegre: LP\&M, 1991.

QUEIROZ, Maria Isaura Pereira. O mandonismo local na vida política brasileira e outros ensaios. São Paulo: Alfa-Ômega, 1976.

O coronelismo numa interpretação sociológica. In. Boris Fausto (Org.) História Geral da Civilização Brasileira. 4ª ed., tomo III. v.1., São Paulo: DIFEL, 1985.

SÁ, Giovanni Alves Duarte. Honra, poder e parentela política: reflexões sociológicas a partir de um estudo de caso no sertão pernambucano. Revista Cadernos de Campo. Araraquara (SP). n. 25, p. 209-228. Jul./Dez. 2018.

SCHWARCZ, Lilia. Sobre o autoritarismo brasileiro. São Paulo: Companhia das Letras, 2019.

SOARES, Cristiano. Pereiras e Carvalhos: uma história da espacialização das relações de poder (Serra Talhada-PE). 2015. 149 f. Dissertação (Mestrado em História) - Universidade Federal do Rio Grande do Norte. Natal, 2015.

VILLELA, Jorge Mattar. O povo em armas: violência e política no Sertão de Pernambuco. Rio de Janeiro: Relume Dumará, 2004.

WILSON, Luís. Vila Bela, os Pereiras e outras histórias. $2^{\mathrm{a}}$ ed. Recife: Centro de Estudos de História Municipal (CEHM), 2018. 